\title{
Review of the book "Noonomy" by Sergey Bodrunov
}

\author{
Vladimir Plotnikov* \\ Professor of Department of General Economic Theory \& History of Economic Thought, University of Economics, Russia
}

Submission: June 04, 2019; Published: June 13, 2019

*Corresponding author: Vladimir Plotnikov, Professor of Department of General Economic Theory \& History of Economic Thought, University of Economics, Russia

\section{Mini Review}

"Noonomy" by Sergey Bodrunov was published in 2018. This is a 432-page book that was the result of the author's extensive research [1]. This book is devoted to the analysis of social changes in the modern world. Professor Bodrunov, following the Marxist tradition, considers social transformations through the lens of economic development. Based on the study of economic and technological trends, he formed a model of social evolution. This model adequately describes many current situations. The model also has serious predictive abilities. In this regard, this book can be attributed to the category of social futurology. The key category of the book is "Noonomy". This is a new term proposed by Sergey Bodrunov. To them he denotes the future model of the society structure. In this model, relationships between people will change. This relationship will cease to be economic. And the economy will not be a key factor in the development of society. The reason for these changes is the rapid development of technology. Some signs of these transformations are visible today. Robots in production actively replace people [2]: according to Brookings Institution, in the coming decades, about 36 million jobs in the United States will be subject to a high degree of automation, and another 52 million - an average degree of automation. This can lead to a massive release of labor. Fundamental social transformations will result from these changes.

In modern science and public discourse, there are various assessments of the changes taking place. These opinions are often the opposite. Professor Bodrunov suggests a combined vision of the changes in question. He combines in his theory the technocratic and humanistic approaches, his ideas are based on the concept of social progress (Marquis de Condorcet, 1785). Bodrunov believes that the "historical fork" will be successfully overcome by mankind. A person's ability to improve is limitless, but the implementation of this ability requires some institutional changes. These changes are the subject of scientific analysis in the book under review. The main part of the book consists of three sections. The first section of the book is devoted to the analysis of changes in the economic system caused by the development of technology. This section is called "Nooproduction: the runup." On a significant amount of empirical and theoretical material, the author proves that the trend for the development of post-industrial society was short-term. It is not fundamental. The basic idea of post-industrialism, as Bodrunov writes, is a "mirage". He believes that the true vector of development of modern society should be associated with the evolution of the concept of "New Industrial State" by John Kenneth Galbraith [3]. In this logic, the main line of development is not in direction: an industrial society - a new industrial society - a post-industrial society, but in a direction: an industrial society - a new industrial society - a new industrial society of the 2 nd generation (NIS.2). The crisis of the concept of post-industrialism, the author of the book argues the emergence of "new normality" [4].

"The Limits to Growth" was predicted almost half a century ago [5]. And these limits are not reached due to the depletion of natural resources, but because of the exhaustion of the development potential of the existing social model. Therefore, this model requires revision. Rapid technological development, the Fourth Industrial Revolution [6] led to a change and complication of production methods. It changed the economic and social relations. The new industrial society of the $2^{\text {nd }}$ generation is a society with technological leaders in the field of information and communication (digital) and cognitive technologies. And these leaders in the world are changing today. This leads to new interstate contradictions, which cannot be resolved within the framework of the paradigm of postindustrial society. The largest countries of the world, including the developed ones, under these conditions are carrying out the "new" industrialization. This corresponds to the trend highlighted by Professor Bodrunov for the development of the NIS.2. New industrialization differs from those industrializations known to history. It is built on a new technological basis. New 
production, above all, is based on the generation and use of new knowledge. To denote this phenomenon, the author uses the term "knowledge-intensive industrial production." The product of such production is also transformed. The product becomes a "knowledge-capacious product," which leads to structural shifts in the economy. Further, these changes affect first the culture of consumption, then the culture as a whole and, finally, through a series of institutional transformations, the entire society.

That is, the development of technology drastically affects the social structure, leads to its qualitative change, the result of which is the formation of "Noonomy". This is a new type of society. In it there will be a division of human life activity into a social system and an economic (production) system. The description of this phenomenon is devoted to the second section of the book. It has the name "Noosphere and nonproduction". By "Noonomy" the author means a non-economic way of organizing an economy. Noonomics is a system that differs from economics in the absence of human relations in the process of material production. Unlike all previous stages of the development of civilization, individuals do not enter into noon my with each other in the production process. Two different areas of the civilizational structure - production (the technosphere, without people) and human society enter into relations with each other. The development of NIO.2, leading to the "squeezing" of people out of production, is preparing a transition to such a structure of human civilization. For the first time in the history of the technosphere separated from human society. This leads to the fact that the basis of civilizational development, as interpreted by Karl Marx (production relations), will disappear. There will be a new type of relationship between society and the Technosphere (but not between people involved in the Technosphere). These are relations connected with the influence of a person on the sphere of "production without people". Obviously, as this production is intellectualized, feedback will also arise. Technosphere will influence society. According to Professor Bodrunov, many risks and fears are associated with this reverse influence.

There are altogether apocalyptic predictions: mechanisms will subjugate people. These risks are very real. Humanity stands at a "civilization fork", located at the bifurcation point. This state is perceived by many thinkers as a "crisis of civilization". According to the author of the book, the current state is not a fatal crisis. Collective social choice is a normal phenomenon for a developing civilization. But the idea of the dual nature of choice does not correspond to the global vision of the problem. In this situation, one should choose development not according to the "techno-scenario", and not according to the "bio-scenario", but according to the "no-scenario". The general characteristic of this scenario of civilization development is considered by the author in his book. In his analysis, Professor Bodrunov is based on the concept of Russian cosmism and the theory of the noosphere proposed by Vladimir Vernadsky. The term "noosphere" has a Greek origin and literally means "sphere of mind". As Vernadsky, as well as his followers Pierre Teilhard de Chardin and Édouard Le Roy, in the noosphere, intelligent human activity becomes the determining factor in the development of not only civilization, society (including the technosphere), but natural processes. Bodrunov believes that the "knowledge-capacity" and "knowledge-intensity" noted above are manifestations of noospheric development.

At the same time, the Bodrunov noonomy is not a "noospheric economy". The treatment of this category is much broader. ("Noonomy" is not equal to "noosphere" plus "economy"!) Noonomн is a new model of a civilizational structure that will replace NIO.2.

The development of technology over time will lead to the complete ousting of man from the sphere of social life, which is now called the "economy". As a result, this sphere will cease to be an element of society, since there will be no more person in it, there will be no relations between people about production. New technologies autotomize production, a new way of social organization will arise, where production activities will no longer be economic, social. And this possible future way of social organization, Professor Bodrunov, calls the term "noonomy". The first part of the word "noonomy" ("noo-") in the interpretation of Professor Bodrunov goes back to the Greek word for "knowledge", "reason". The second part of the term under consideration ("nomos") is also of Greek origin. This is the law, order, way of life, principle of organization. According to Professor Bodrunov, "noonomy is a way of satisfying needs in a society where there is a "light of reason" and where there is no relationship to production, and production relations where there is no relationship to property, and property relations where there is no economy. This is a non-economic way of meeting human needs". The third part of the book is called "On the way to noonomy". It has practical value. This is quite unexpected for such a deep theoretical study, which describes the fundamental trends in the development of civilization and attempts to predict its future appearance. Professor Bodrunov in this part of the book develops recommendations for accelerating the formation of a new model of human society. He analyzed specific issues of industrial, monetary, social, etc. politics.

The author identified the risks of their implementation, justified recommendations for identifying best practices and their use. He argues that NIS.2 and noonomy cannot form spontaneously. They cannot be "declared" Directive or Order. These new models are evolving. We, contemporaries of this process, understanding its essence and direction, can speed up or slow it down, give it new accents. A special role in this belongs to both states and supranational regulatory mechanisms, as well as to the institutions of civil society.

As the analysis of the trends observed today shows, the extent of human presence in the social and economic systems changes. And this is reflected in the statistics regarding the ratio of working time and leisure time. Technological progress is "crowding out" people from the economic system to the social 
one. And we, the participants of this process, so to speak at the micro level of its occurrence, this trend cannot but dislike. Due to the progress in technology, a person can devote less time to earning "his daily bread", and more time - to self-development, education, creativity, communication, entertainment, etc. Therefore, the issues of humanitarian development, development of culture, overcoming social conflicts, support for science and education, etc. come to the fore today. Neither technology nor organizational success will make humanity happy. The formation of a new civilization (noonomy), according to Professor Sergey Bodrunov, requires, first of all, the development of Man himself. And with this thought one should agree.

\section{References}

1. Bodrunov S (2018) Noonomy, Moscow, St. Petersburg, London, UK, p. 432.
2. Carson E (2019) Robots could replace humans in a quarter of US jobs by 2030

3. Galbraith JK (2007) The New Industrial State, Princeton University Press, USA, pp. 518.

4. Goldberg S (2010) Investing in the New Normal: Pimco's Mohamed ElErian aims at making profits and reducing risks in an uncertain time with his Global Multi-Asset fund.

5. Donella H Meadows, Dennis L Meadows, Jørgen Randers, William W Behrens (1972) The Limits to Growth: A Report for the Club of Rome's Project on the Predicament of Mankind. Universe Books. p. 211.

6. Schwab K (2017) The Fourth Industrial Revolution. Penguin. p. 192

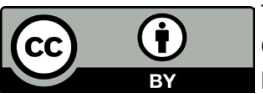

his work is licensed under Creative Commons Attribution 4.0 License DOI: 10.19080/GJAA.2019.09.555771 